\title{
Moet een drempel van aannemelijkheid worden genomen om recht te hebben op inzage in gegevens op grond van art. $843 \mathrm{a} \mathrm{Rv}$ ?
}

\author{
Mr.J. Ekelmans*
}

\begin{abstract}
1 De vraagstelling
Of inzage kan worden verkregen in andermans papieren, computerdata of andere gegevens is van groot praktisch belang. Dat kan immers de uitkomst bepalen bij een schier onuitputtelijk aantal mogelijke geschillen over de volle breedte van het vermogensrecht. Wie een zoekopdracht intikt op www.rechtspraak.nl op het relevante wetsartikel - art. 843a $\mathrm{Rv}$ - krijgt dan ook meer dan 400 hits per jaar. Dat praktisch belang blijkt ook uit het gebruik van literatuur over art. 843a $\mathrm{Rv}$. Het artikel is digitaal het meest geraadpleegde artikel in de Groene Serie Burgerlijke rechtsvordering.
\end{abstract}

Actueel is de vraag of een vordering voldoende aannemelijk moet zijn om inzage te rechtvaardigen: de vraag is besproken in januari en februari van dit jaar in door A-G Wesseling-van Gent genomen conclusies, ${ }^{1}$ en is een niet onbelangrijk onderdeel van een op 17 juni 2020 door de Minister voor Rechtsbescherming ingediend wetsontwerp tot vereenvoudiging en modernisering van het bewijsrecht ${ }^{2}$ én staat centraal in het op 10 juli 2020 door de Hoge Raad gewezen Semtexarrest. $^{3}$

Controversieel is het onderwerp evenzeer. Was het maar zo, dat de klokken van de advocaat-generaal, de expertcommissie die de minister heeft geadviseerd, waarover zo direct meer, de Hoge Raad en de wetgever gelijkliepen. Zo is het echter niet. De advocaat-generaal, de expertcommissie, de wetgever en de Hoge Raad zitten nog niet merkbaar op één lijn. Reden genoeg om onder ogen te zien welk antwoord is geboden. En bovenal: waarom? Daarover gaat dit artikel. Ik concentreer mij daarbij op de vraag die centraal staat, kap het hout eromheen dat het zicht op dit thema belemmert, én laat zien hoe de gedachte-

\footnotetext{
* Mr. J. Ekelmans is advocaat bij Ekelmans \& Meijer Advocaten in Den Haag.

1. Conclusies A-G Wesseling-van Gent d.d. 3 januari 2020, ECLI:NL:PHR:2020:10 en d.d. 7 februari 2020, ECLI:NL:PHR: 2020:128

2. Kamerstukken II 2019/20, 35498, nr. 1 e.v.

3. HR 10 juli 2020, ECLI:NL:HR:2020:1251 (Semtex/X c.s.).
}

vorming over dit thema in het recente verleden heeft plaatsgehad. En: ik geef aan hoe de vraag wat mij betreft nu én in de toekomst beantwoord moet worden.

\section{Het belang van het onderwerp voor de praktijk} De vraag is praktisch van belang. Dat laat zich goed illustreren aan de hand van de zaak waarover de Hoge Raad oordeelde. Die gaat over twee dames werkzaam bij een bedrijf dat kinderkleding ontwerpt en verkoopt, de een als hoofd inkoop, de ander als ontwerpster. Beide dames nemen enige tijd na elkaar ontslag en zijn spoedig nadien betrokken bij een door één van hen opgerichte concurrerende onderneming. Een van hen stuurt kort voor haar vertrek enkele bestanden naar haar privé-e-mailadres. Beide dames laten op de computer van hun oud-werkgever een leeg bureaublad en een lege e-mailbox achter. Bij de nieuwe onderneming zijn zij actief, hoewel zij, althans volgens hun oud-werkgever, hadden gezegd meer tijd te willen besteden aan hun gezin of aan een studie. De oudwerkgever meent dat de beide dames hun geheimhoudingsbeding en verbod op nevenwerkzaamheden hebben overtreden, legt met verkregen verlof bewijsbeslag en vordert inzage in bestanden aangetroffen op de computers van het nieuwe bedrijf om een op die schending gebaseerde vordering te onderbouwen. Voor de beide dames lag, hoop ik, succes met hun nieuwe venture in het verschiet. Anders zou het voor de ex-werkgever een beetje zonde zijn om in een rechtszaak in drie instanties over dit onderwerp te investeren.

Het cassatiemiddel geeft een mooie opsomming van de stellingen en veronderstellingen waarop de oud-werkgever baseerde dat het geheimhoudingsbeding en het verbod op nevenwerkzaamheden waren geschonden. ${ }^{4} \mathrm{Ik}$ laat die opsomming rusten. Ik volsta met de observatie dat het een getergde cliënt en bekwaam advocaat meer dan eens gegeven zal zijn om samen optrekkend ook in andere zaken soortgelijke stellingen en veronderstellingen aan te voeren, die vervolgens door een weder-

4. Conclusie A-G Wesseling-van Gent d.d. 7 februari 2020, ECLI:NL:PHR:2020:128, onder 2.60. 
partij met begenadigde bijstand deels betwist en deels verklaard worden. De rechter die vervolgens doet wat alleen hij of zij kan, een beslissing nemen, zal maar al te vaak komen bij hetzelfde springende punt: is voor aanspraak op inzage vereist dat voldoende aannemelijk is dat van de beweerdelijke schending sprake is?

\section{De onduidelijkheid van de huidige wettekst}

\subsection{De onduidelijke wettekst}

Voor de procespartij die haar knopen moet tellen én de rechter die de knoop moet doorhakken, zou het prettig zijn als de wetgever de weg had gewezen met een heldere wettekst, waaruit het antwoord blijkt op de vraag waarover dit artikel gaat. Zo is het echter niet: wat mij betreft behoort art. $843 \mathrm{a} \mathrm{Rv}$ tot de meer ondoorgrondelijke artikelen uit het burgerlijk procesrecht. Ik neem het eerste lid. Dat luidt:

'Hij die daarbij rechtmatig belang heeft, kan op zijn kosten inzage, afschrift of uittreksel vorderen van bepaalde bescheiden aangaande een rechtsbetrekking waarin hij of zijn rechtsvoorgangers partij zijn, van degene die deze bescheiden te zijner beschikking of onder zijn berusting heeft. Onder bescheiden worden mede verstaan: op een gegevensdrager aangebrachte gegevens.'

In de tekst staat een reeks begrippen die allemaal geduid moeten worden om betekenis aan het artikel te geven. Die duiding vindt ook plaats in veel rechterlijke uitspraken waarin die begrippen als het ware worden afgevinkt om tot een oordeel te komen. Aan het oog ontrolt zich een lawyer's paradise en daarmee een nachtmerrie voor cliënten en rechters, wanneer die snel en makkelijk een beslissing willen nemen. Daarmee opent zich een terrein groot genoeg voor onder meer twee proefschriften in 2010 over slechts dit ene artikel. 5 De proefschriften markeerden de ontdekking en ontwikkeling van het inzagerecht. Die ontwikkeling was nog maar van vrij recente datum. Voor de beeldvorming: zo'n twintig jaar terug waren de gepubliceerde uitspraken over art. 843a Rv op de vingers van twee handen te tellen. Het artikel ging in de literatuur door het leven als een artikel over de 'bijzondere exhibitieplicht'. Een uithoek van het recht.

\subsection{Een kritisch ontvangen wetsontwerp uit 2011 ter verbetering van het inzagerecht}

Die ontdekking en ontwikkeling van het inzagerecht was ook de Minister van (toen) Veiligheid en Justitie niet ontgaan. Hij werd aangestoken door een behoefte om het inzagerecht te verbeteren. Dat gaf hij als reden voor de indiening - in 2011 van een wetsontwerp. ${ }^{6}$ Wanneer er wel of niet sprake was van

5. J.R. Sijmonsma, Het inzagerecht: artikel 843 a van het Wetboek van Burgerlijke Rechtsvordering (diss. Maastricht), Deventer: Kluwer 2010; J. Ekelmans, De exhibitieplicht (diss. Groningen), Deventer: Kluwer 2010.

6. Kamerstukken II 2011/12, 33079, nr. 3, p. 1, waarover J. Ekelmans, Het inzagerecht verbeterd?, NTBR 2012, afl. 2, p. 49-57, en over het voorontwerp: J.R. Sijmonsma, Het inzagerecht vernieuwd? TvPP 2010, afl. 6, p. 181-182. voldoende belang bij inzage bleef in dit wetsontwerp mistig. Heel veel verder dan de observatie dat de vereisten van subsidiariteit en proportionaliteit aan de rechtspraktijk beoordelingsruimte zouden moeten geven, ${ }^{7}$ én dat aan de rechter een zekere discretionaire bevoegdheid toekomt, ${ }^{8}$ kwam de minister niet. Een belangrijk, toen nog ongeregeld onderwerp - bewijsbeslag - liet de minister onaangeroerd, zodat de Hoge Raad zich later geroepen voelde in het gat te springen en een normenkader voor bewijsbeslag schetste. ${ }^{9}$ Het wetsvoorstel werd in de Tweede Kamer kritisch ontvangen met onder meer een reeks vragen vanuit een regeringsfractie waaruit de vrees sprak dat de sluizen van het inzagerecht te wijd opengezet zouden worden. ${ }^{10}$

\section{De minister vraagt advies over modernisering van het gehele bewijsrecht}

Geconfronteerd met deze parlementaire tegenwind tegen zijn geesteskind koos de minister voor een beproefd politiek concept: het vragen van advies aan een commissie. ${ }^{11}$ Net zoals bij een procedure waarin de rechter een deskundigenbericht vraagt, doen de vraag én de keuze van de deskundigen er dan toe. Wat zou het leuk zijn geweest om als een vlieg op de muur te zitten bij het overleg dat de minister gevoerd zal hebben over dat thema. Over de inhoud van dat overleg geven openbare stukken geen uitsluitsel. Wel over het resultaat. De minister koos niet voor het verrichten van empirisch onderzoek naar het probleem dat hij dacht te zien én wilde oplossen, het raadplegen van een groep uit degenen die inzage plegen te vragen of zich daartegen plegen te verweren, het consulteren van een groep rechters en advocaten die hun tanden op het thema stukbijten óf het inzetten van het WODC.

De minister schakelde op: hij koos voor het vragen van advies over modernisering niet alleen van het inzagerecht, maar van het volledige bewijsrecht. Dat advies vroeg hij aan drie hoogleraren, die allen hun sporen hadden verdiend met adviezen om de rechtspleging niet bij het oude te laten: Daan Asser (een van de auteurs van een enthousiasmerend rapport over de fundamentele herbezinning van het burgerlijk procesrecht met daarin ook het begin van een pleidooi voor de uitbouw van het inzagerecht ${ }^{12}$ ), Ruth de Bock (auteur van een gelauwerd proefschrift over waarheidsvinding ${ }^{13}$ ) en Fred Hammerstein (naamgever van onder meer een commissie die de civiele cassa-

7. Kamerstukken II 2011/12, 33079, nr. 3, p. 11.

8. Kamerstukken II 2011/12, 33079, nr. 3, p. 13.

9. HR 13 september 2013, ECLI:NL:HR:2013:BZ9958, NJ 2014/455 (Molenbeek Invest/Begeer c.s.).

10. Kamerstukken II $2011 / 12,33079$, nr. 5 .

11. Kamerstukken II 2014/15, 34059, nr. 6, p. 44.

12. W.D.H. Asser, H.A. Groen \& J.B.M. Vranken, Uitgebalanceerd. Eindrapport fundamentele herbezinning Nederlands burgerlijk procesrecht, Den Haag: Boom Juridische uitgevers 2006, p. 71-76.

13. R.H. de Bock, Tussen waarheid en onzekerheid: over het vaststellen van feiten in de civiele procedure (diss. Tilburg), Deventer: Kluwer 2011. 
tiepraktijk had opgeschud ${ }^{14}$ en regeringscommissaris voor de wetsvoorstellen over digitalisering van de civiele procedures ${ }^{15}$ ).

De expertgroep toog aan de slag in 2014 en volgde een vertrouwd pad bij juridisch onderzoek van de gevraagde soort: het opstellen van concept(deel)notities over onderwerpen, het bespreken daarvan met de adviescommissie burgerlijk procesrecht, het in een tweetal door het ministerie georganiseerde bijeenkomsten raadplegen van groepen geïnteresseerden wier mening ertoe zou kunnen doen, én het uitbrengen van een advies, dat vervolgens in april 2017 bij de minister op de mat viel. ${ }^{16}$ Kort nadien trok de minister het wetsontwerp uit 2011 in. ${ }^{17}$

\section{Het beperkte belang van aannemelijkheid in het advies van de expertgroep}

\subsection{De keuze voor aansluiting bij de normen voor voorlopig getuigenverhoor en de daarbij behorende beperkte betekenis van aannemelijkheid}

Hoeksteen in het advies van de expertgroep is dat de eisen voor toelating tot voorlopige bewijsmiddelen gelijkgetrokken moeten worden, zodat voor de vordering tot inzage derhalve aansluiting gezocht moet worden bij de eisen die ook bij voorlopige getuigenverhoren én voorlopige deskundigenberichten gelden. ${ }^{18}$ Zo'n verzoek moet in beginsel worden toegewezen, tenzij belang daarbij ontbreekt, er sprake is van misbruik van recht of strijd met de goede procesorde, of een gewichtige reden zich tegen toewijzing verzet. Voor voorlopige getuigenverhoren geldt van oudsher dat bij die beoordeling geen rol speelt of de voorgenomen vordering aannemelijk is. ${ }^{19}$ Wat (on)waar is én of een vordering kansrijk of kansarm is, moet immers maar vastgesteld worden na het voorlopig getuigenverhoor.

De expertgroep was zich ervan bewust dat de Hoge Raad in 2016 een arrest had gewezen (waarover straks meer), waarbij bij inbreuk op IE-rechten strengere eisen werden gesteld aan de aannemelijkheid bij een vordering tot inzage. Volgens de expertgroep was het vooralsnog niet nodig om aansluiting te zoeken bij dit arrest. ${ }^{20} \mathrm{~W}$ aarom dat nog niet noodzakelijk is én wat er voor nodig zou zijn om dat wel noodzakelijk te maken,

14. Kamerstukken II 2008/09, 29279, nr. 69, bijlage: rapport versterking cassatierechtspraak.

15. Kamerstukken II 2014/15, 29279, nr. 210.

16. A. Hammerstein, R.H. de Bock \& W.D.H. Asser, Modernisering burgerlijk bewijsrecht, Den Haag: Boom juridisch 2017; ook te vinden onder: Kamerstukken II 2016/17, 29279, nr. 384, bijlage, waarover o.m. H.F.M. Hofhuis, Uitgangspunten van de expertgroep modernisering bewijsrecht, TvPP 2017, afl. 5, p. 155-161; J. Ekelmans, De drie keuzes over het inzagerecht van de expertgroep bewijsrecht, TvPP 2017, afl. 5, p. 176-184; Y.A. Wehrmeijer \& E.M. Hoogervorst, Naar een moderner burgerlijk bewijsrecht, TCR 2018, afl. 1, p. 1-9.

17. Kamerstukken II 2017/18, 33079, nr. 7.

18. Advies expertgroep, randnr. 102 e.v.

19. HR 6 juni 2008, ECLI:NL:HR:2008:BC3354, NJ 2008/323 (R/Staat) en HR 19 maart 2010, ECLI:NL:HR:2010:BK8146, NJ 2010/172 (Chipshol/Staat).

20. Advies expertgroep, randnr. 144. expliciteert de expertgroep niet. De aannemelijkheid van de vordering krijgt ook verder geen prominente plaats in het advies. Slechts wordt aangegeven dat voldoende belang kan (!) ontbreken wanneer er in het geheel geen vordering meer is. ${ }^{21}$ De aannemelijkheid van de vordering doemt pas op wanneer bij misbruik van recht wordt aangegeven dat de aannemelijkheid van de vordering een van de gezichtspunten is die een rol kan spelen bij de beoordeling of sprake is van misbruik van recht. $^{22}$

\subsection{Is het juist om de normen voor het inzagerecht gelijk te trekken aan die voor voorlopige getuigenverhoren?}

De expertgroep rekende het niet tot zijn taak om de bestaande feitenrechtspraak over het vereiste rechtmatig belang te analyseren, en laat die onbesproken. ${ }^{23}$ Ik denk ook niet dat zo'n analyse veel zin zou hebben gehad en slechts één steen der wijzen naar boven had gebracht. ${ }^{24}$ Voor wie over het ontbreken van die analyse heen stapt, oogt de oplossing van de expertgroep bij eerste beschouwing mooi: hoe meer uniform toepasselijke normen, hoe beter het is, zou ik zeggen. Echter, het gebruik van één en dezelfde norm voor alle gevallen veronderstelt dat de gevallen waarop de norm toepasselijk is én de belangen die daarbij spelen, onderling voldoende vergelijkbaar zijn. Kortom: dat de belangen bij een verzoek om getuigen te horen en de belangen bij inzage voldoende overeenstemmen.

Ik denk dat verdere overdenking laat zien dat de belangen wezenlijk verschillen. Discussies over wel of niet toelaten tot getuigenverhoor zijn er relatief weinig, getuigenverhoren komen in de praktijk niet veel voor, het aantal getuigen is doorgaans beperkt, het aantal aan hen te stellen vragen overzichtelijk, en zij hoeven slechts uit eigen wetenschap te verklaren en zich dus niet op een getuigenverhoor voor te bereiden door archiefonderzoek of een andere vorm van intern onderzoek te doen om feiten te achterhalen die hun niet uit eigen wetenschap bekend zijn. ${ }^{25}$ De hoeveelheid fysieke en digitale gegevens is schier onuitputtelijk en dijt dagelijks uit, fysieke en digitale gegevens kunnen bij allerlei verschillende mensen én op verschillende plaatsen aangetroffen worden, en documenten en data spelen bij de meeste geschillen een rol. Discussies over het wel of niet verstrekken van bescheiden doen zich vaker voor dan discussies over het horen van getuigen én partijen moeten gevraagde gegevens verzamelen: het is - anders dan bij getuigenverhoor - geen optie om zich te beperken tot hetgeen uit eigen wetenschap bekend is en archiefonderzoek of andere vormen van intern onderzoek achterwege te laten. Het (moeten) verzamelen van digitale en fysieke gegevens kan makkelijk zeer bewerkelijk zijn

21. Advies expertgroep, randnr. 110.

22. Advies expertgroep, randnr. 122.

23. Advies expertgroep, randnr. 104.

24. Zie voor verschillende opvattingen destijds bijv. conclusie A-G Van Peursum d.d. 14 augustus 2015, ECLI:NL:PHR:2015:1664, onder 2.9-2.13. Zie voor een recent overzicht J.R. Sijmonsma, Het inzagerecht van art. 843a Rv nader bezien, TvPP 2019, afl. 4, p. 103-110.

25. HR 19 september 2003, ECLI:NL:HR:2003:AF8273, NJ 2005/454, r.o. 3.6 en HR 12 juni 2020, ECLI:NL:HR:2020:1046, r.o. 3.3.2. 
omdat de gegevens opgezocht en zo nodig geselecteerd moeten worden. Onder omstandigheden zal telkens beoordeeld moet worden of te midden van die gegevens informatie zit die vertrouwelijk is én vertrouwelijk mag blijven. Bij het normenkader dat de expertgroep voorstaat, valt te verwachten dat de belasting die het inzagerecht op partijen én op niet bij het geschil betrokken derden legt, toeneemt. Die last treft zowel de bezitters van informatie als hen die moeten nagaan of zij over informatie beschikken. Uitgangspunt is immers wat de expertgroep betreft dat stukken verstrekt moeten worden ${ }^{26}$ én dat wie dat niet wil, zal waar moeten maken dat en waarom een uitzondering aan de orde is.

\subsection{De keuze voor verplichte buitengerechtelijke informatie-uitwisseling versterkt het effect van de beperkte betekenis van aannemelijkheid}

De keuze van de expertgroep voor een lage drempel voor vorderingen tot inzage won aan belang door de tweede hoeksteen van het advies: volgens de expertgroep moest uitwisseling van informatie vaker vóór een procedure plaatsvinden. Wie zoekt naar een passage dat aannemelijkheid in die fase wat de expertgroep betreft een grotere rol zou spelen, doet dat vergeefs. De expertgroep bepleit dat partijen zelfredzaam zijn ${ }^{27}$ en dat het buitengerechtelijk uitwisselen van informatie mede onder invloed van bezuinigingen bij de rechtspraak meer dan vroeger van hen verlangd mag worden. ${ }^{28}$ Die opvatting zet de expertgroep kracht bij doordat zij, kort gezegd, bepleit dat informatie die in de voorfase ten onrechte niet is verzameld en verstrekt, tijdens een procedure niet meer gebruikt mag worden. ${ }^{29}$

\section{Het beperkte belang van aannemelijkheid in het wetsvoorstel modernisering bewijsrecht}

Van bevattelijkheid voor eventuele minnen bij de door de expertgroep voor het inzagerecht gemaakte keuzes geeft het in juni dit jaar door de minister ingediende wetsvoorste ${ }^{30}$ geen blijk. Daarin maakt de minister het advies van de expertgroep om de normen voor toelating tot voorlopige bewijsverrichtingen ook toe te passen op het inzagerecht tot het zijne. Waar het wetsontwerp uit 2011 verwarrend onduidelijk was over de eisen waaraan voldaan moest worden om inzage te kunnen verlangen, kiest het wetsvoorstel uit 2020 voor aansluiting bij de eisen voor voorlopige bewijsmiddelen en is er dus maar weinig voor nodig om inzage te verkrijgen.

26. Advies expertgroep, randnr. 69.

27. Advies expertgroep, randnr. 34.

28. Advies expertgroep, randnr. 21.

29. Advies expertgroep, randnr. 41-42.

30. Kamerstukken II 2019/20, 35498, nr. 1 e.v.; zie over het voorontwerp S.L. Boersen \& T.R.B. de Greve, Information overload en de meeprocederende rechter. Kanttekeningen bij het Conceptwetsvoorstel vereenvoudiging en modernisering bewijsrecht, BER 2018, afl. 8, p. 20-25 en R. Ubels \& T. van Amsterdam, Kritische beschouwing over het wetsontwerp ter vereenvoudiging en modernisering van het bewijsrecht, TCR 2019, afl. 1, p. 22-32.
In aansluiting op het advies van de expertgroep wint deze maatstaf aan praktisch belang door de nadruk op preprocessuele verzameling van bewijs. Het wetsvoorstel benadrukt dat partijen gegevens vóór een procedure moeten verzamelen, ${ }^{31}$ dat gegevens desgevraagd ook vóór de procedure verstrekt moeten worden, ${ }^{32}$ én dat de rechter een geraden gevolgtrekking ${ }^{33}$ kan maken indien een partij de redelijkerwijs van haar te vergen inspanningen om informatie te verzamelen achterwege heeft gelaten. ${ }^{34}$ De tanden van de sanctie zijn in de toelichting gepolijst: de geraden gevolgtrekking zou volgens de memorie van toelichting in elk geval niet moeten bestaan uit volledige bewijsuitsluiting. ${ }^{35}$

Het belang van de maatstaf laat zich ook gelden wanneer in de fase vóór een bodemprocedure gebruik wordt gemaakt van de mogelijkheid een verzoekschrift in te dienen teneinde inzage van een ander te verkrijgen. ${ }^{36}$ De uitspraak op dat verzoek wil de minister belasten met een appelverbod, ${ }^{37}$ dat naar huidig recht ontbreekt. ${ }^{38}$ Wat de minister betreft bepaalt de rechter die de uitspraak doet zelf of hoger beroep openstaat. Voor degene die inzage moet verstrekken, betekent het ontbreken van de mogelijkheid hoger beroep in te stellen dat hij bij een veroordeling hoe dan ook gehouden is om inzage te verlenen. Degene wiens verzoek tot inzage wordt afgewezen, kan daarentegen wat de minister betreft, als de omstandigheden anders zijn komen te liggen, een nieuw verzoek tot inzage indienen. ${ }^{39}$ Wat mij betreft is het handhaven van de bestaande mogelijkheid om een rechtsmiddel aan te wenden evenwichtiger. De betrokkenen bij inzage verdienen een betere rechtsbescherming nu de ontgroening van het inzagerecht nog maar net achter de rug is en het inzagerecht zich nog verder zal moeten ontwikkelen. De gebruikelijke toegang van partijen tot de hoven en de Hoge Raad faciliteert gemakkelijker de uniforme toepassing en ontwikkeling van het inzagerecht.

Terwijl zijn voorganger nog aangaf dat advies over bewijsrecht ook werd gevraagd om betekenis te geven aan Europese ontwikkelingen op het gebied van het bewijsrecht, ${ }^{40}$ schrijft de minister het arrest van de Hoge Raad uit 2016 over hogere eisen bij IE-rechten weg door op te merken dat die rechtspraak gewezen is onder een EU-richtlijn, betrekking heeft op een specifiek rechtsgebied en geen bredere toepassing verdient. ${ }^{41}$ Het antwoord op de onder meer door de Hoge Raad aan de minister gestelde vraag over de betekenis van dit arrest uit

31. Art. 21 lid $2 \mathrm{Rv}$ (nieuw).

32. Art. $194 \mathrm{Rv}$ (nieuw).

33. Zie daarover recent C.J.A. Seinen, De waarheidsplicht en de geraden gevolgtrekking anno 2020: een zoektocht naar proportionaliteit, TCR 2020, afl. 2, p. 33-47.

34. Art. 21 lid $3 \mathrm{Rv}$ (nieuw).

35. Kamerstukken II 2019/20, 35498, nr. 3, p. 30.

36. Art. 196 e.v. Rv (nieuw).

37. Art. $200 \mathrm{Rv}$ (nieuw).

38. Kamerstukken II 2019/20, 35498, nr. 3, p. 63.

39. Kamerstukken II 2019/20, 35498, nr. 3, p. 63.

40. Kamerstukken II 2014/15, 34059, nr. 6, p. 44.

41. Kamerstukken II 2019/20, 35498, nr. 3, p. 47. 
$2016^{42}$ wordt aldus in één zin weggemoffeld in een memorie van toelichting die verder niet echt kort van stof is. Van een in 2018 door de Hoge Raad gewezen arrest over evenzeer hogere eisen bij inzagevorderingen bij bedrijfsgeheimen rept de memorie van toelichting niet. Verschillende fracties zetten in het in oktober 2020 ingediende verslag vraagtekens bij en stellen vragen over de reikwijdte van de in het wetsvoorstel opgenomen informatieplichten. ${ }^{43}$ De door de Hoge Raad gewezen arresten en de daarbij gestelde eisen aan aannemelijkheid komen in die vragen niet aan de orde. Reden genoeg om nieuwsgierig te worden naar die arresten. Daarover het volgende.

\section{Voldoende aannemelijkheid vereist volgens de Hoge Raad?}

\subsection{De vereiste voldoende aannemelijkheid volgens de arresten over IE-rechten en bedrijfsgeheimen}

Op het moment dat de expertgroep de minister adviseerde, was er één relevant arrest, op het moment dat de minister zijn wetsvoorstel indiende, waren het er twee over de eisen aan aannemelijkheid. Het eerste arrest ging over inzagerecht bij gestelde inbreuk op IE-rechten, ${ }^{44}$ het tweede over inzagerecht bij gestelde inbreuk op bedrijfsgeheimen. ${ }^{45}$ In beide arresten overwoog de Hoge Raad tot de kern teruggebracht dat de eisen voor toewijzing van een vordering het lichtste zijn bij bewijsbeslag (dan mag de beslaglegger immers geen inzage nemen: beslag strekt slechts tot bewaren van bewijs), zwaarder bij het daadwerkelijk nemen van inzage en het zwaarst bij het toewijzen van een op de verkregen gegevens gebaseerde vordering.

Gesteld voor de vraag hoe zwaar de eisen dan zijn bij de vordering tot inzage, overwoog de Hoge Raad dat daaraan nog niet was voldaan als die inbreuk voldoende onderbouwd was gesteld. Er was meer nodig: wie inzage verlangt, dient zodanige feiten en omstandigheden te stellen en met reeds voorhanden bewijsmateriaal te onderbouwen, dat voldoende aannemelijk is dat inbreuk op een recht van intellectuele eigendom is of dreigt te worden gemaakt. Wat voldoende aannemelijk is, viel volgens de Hoge Raad niet in algemene zin te zeggen, nu dat - ik voeg toe: zoals in iedere procedure - afhangt van wat is aangevoerd én hoe dat wordt gewaardeerd. Geen blijk van miskenning van die maatstaf gaf - aldus de Hoge Raad - de in de feitenrechtspraak veelal gehanteerde formulering dat uit de door de eiser gestelde (en zo mogelijk met bewijsmateriaal

42. Kamerstukken II 2019/20, 35498, nr. 3, bijlage: advies Hoge Raad, onder 19.

43. Kamerstukken II 2019/20, 35498, nr. 5, zie bijv. par. 4.1: 'Informatiegaring en bewijsverzameling voorafgaand aan een procedure'.

44. HR 13 november 2015, ECLI:NL:HR:2015:3304, NJ 2016/491 (AntiInfringement bureau/Novisem); herhaald in HR 9 december 2016, ECLI:NL:HR:2016:2834 (Synthon/Astellas).

45. HR 28 september 2018, ECLI:NL:HR:2018:1775 (Organik/Dow). gestaafde) feiten en omstandigheden een redelijk vermoeden van een (dreigende) inbreuk moet kunnen worden afgeleid. ${ }^{46}$

\subsection{De discussie of aan deze arresten een bredere betekenis toekwam}

Schriftgeleerden hebben zich op de bewoordingen van de Hoge Raad gestort om vast te stellen of die ook op andere gevallen dan IE-rechten of bedrijfsgeheimen betrekking konden hebben. In het ene arrest gaf de Hoge Raad aan dat de zaak ging over IE-rechten, in het andere dat het ging om bedrijfsgeheimen. Strekten die passages ertoe de betekenis van de uitspraak te beperken tot het in de zaak aan de orde zijnde betrokken rechtsgebied? Waren het slechts beschrijvingen van de toevallige aard van de zaak en had de regel bredere betekenis? Wist de Hoge Raad het zelf nog niet en hield hij zijn kruit droog? Zoveel hoofden, zoveel zinnen. Voor alle opvattingen was een aanhanger te vinden. De duiders van de rechtspraak van de Hoge Raad kregen de tijd om zich daar enige tijd mee bezig te houden. Bijna twee jaar verstreken na het arrest over bedrijfsgeheimen voordat de Hoge Raad zijn gezicht opnieuw liet zien. ${ }^{47}$

Ik doe een kleine ronde langs de spelers op de velden in de volgorde van hun opkomst: volgens de eerste verdienden de uitgangspunten uit het eerste arrest al meteen brede toepassing, ${ }^{48}$ volgens de tweede was dat na het eerste arrest nog niet het geval, ${ }^{49}$ volgens de derde was het tweede arrest zelfs fundamenteel fout, ${ }^{50}$ volgens de vierde bleek uit het arrest daarentegen dat de maatstaf ook gold voor niet-IEzaken, ${ }^{51}$ volgens de vijfde kon het roer na dat tweede arrest definitief om, ${ }^{52}$ en de zesde was daar nu juist weer niet van overtuigd. ${ }^{53}$ Hoe leuk - en hachelijk $k^{54}$ - het ook kan zijn om arresten van de Hoge Raad af te pellen, stemmen te tellen óf het soortelijk gewicht van de argumenten in elk van de reacties te wegen, wat mij betreft is minstens één ding nog leuker. Dat is het stellen van de vraag wat het achterliggende beginsel of belang is op grond waarvan keuzes gemaakt zouden moeten worden.

46. HR 13 november 2015, ECLI:NL:HR:2015:3304, NJ 2016/491 (AntiInfringement bureau/Novisem), r.o. 4.1.5.

47. HR 12 april 2019, ECLI:NL:HR:2019:570 en HR 1 mei 2020, ECLI:NL:HR:2020:830 deden cassatiemiddelen af met toepassing van art. 81 Wet RO.

48. J. Ekelmans, Efficiënt gebruik en beoordeling van inzagevorderingen na HR 13 november 2015, ECLI:NL:HR:2015:3304 (Anti-Infringement bureau/Novisem), NTBR 2016, afl. 2, p. 46-57.

49. R.H. de Bock, Kronieken. Bewijsrecht, TCR 2016, afl. 2, p. 55.

50. Annotatie W.J.G. Maas bij het Organik/Dow-arrest, BIE 2018/34, p. 268-269.

51. Th.C.J.A. van Engelen, Organik v Dow Chemical: het achterhalen van geheim bewijs van een geheime inbreuk op een bedrijfsgeheim, AA 2019, p. 692

52. Sijmonsma 2019, p.108 en 109.

53. Conclusie A-G Wesseling-van Gent d.d. 7 februari 2020, ECLI:NL:PHR:2020:128, onder 2.43.

54. F.B. Bakels, Rode draad 'Rechtsvorming door de Hoge Raad': totstandkoming en uitleg van uitspraken van de Hoge Raad, AA 2010, afl. 6, p. 927-938. 


\subsection{Het oordeel dat bij alle inzagevorderingen voldoende aannemelijkheid vereist is}

Twee jaar na het arrest over bedrijfsgeheimen kwam het antwoord. Dat gebeurde met het Semtex-arrest van 10 juli $2020.5^{5}$ Op de vraag naar het achterliggende beginsel of belang, geeft de Hoge Raad antwoord in dit arrest, maar niet meteen. Eerst oefent de Hoge Raad het voorrecht uit dat vooral een rechter heeft: met één pennenstreek een discussie beslechten waaraan anderen pagina's tekst hebben gewijd. Kernachtig overweegt de Hoge Raad dat de eisen die hij heeft gesteld voor toewijzing van een vordering tot inzage in de eerdere arresten over IE-rechten en bedrijfsgeheimen ook gelden voor de beoordeling van andere vorderingen op grond van art. 843a Rv. In stand hield de Hoge Raad het oordeel van de feitenrechter dat de beide ondernemende dames geen inzage behoefden te geven in de computerdata van hun bedrijf in kinderkleding.

Met het gegeven oordeel zou kunnen gelden Roma locuta, causa finita, maar dat zou wel erg mager zijn. Immers: dan blijft ongewis waarom de Hoge Raad tot zijn oordeel komt. In die duisternis laat de Hoge Raad zijn lezers niet. Vervolgens geeft de Hoge Raad aan waarom dat wat hem betreft zo is: volgens de Hoge Raad stelt die maatstaf de rechter in staat een evenwicht te vinden tussen het belang van eiser of verzoeker om de waarheid te kunnen achterhalen en zijn bewijspositie te versterken, en het belang van verweerder om geen vertrouwelijke informatie prijs te hoeven geven en verschoond te blijven van de ingrijpende maatregel die exhibitie niet zelden is. ${ }^{56}$ In de gevraagde aandacht voor het ingrijpende karakter dat exhibitie niet zelden heeft, ligt de reserve die wat mij betreft ten onrechte bij het advies van de expertgroep en het wetsontwerp van de minister ontbreekt. Dat ingrijpende karakter is natuurlijk niet voorbehouden aan inzagevorderingen over - bijvoorbeeld - IE-recht en daarom overtuigde en overtuigt de wijze waarop het arrest over IE-recht door de expertgroep en de minister was weggeschreven (mij) niet.

Het arrest vervolgt bij wege van toegift met een passage die bevestigt wat een raadsheer in de Hoge Raad zegt wanneer je hem of haar 's nachts wakker makkt en een vraag stelt. ${ }^{57}$ Nog voordat de ogen zijn uitgewreven, komen in het antwoord op die vraag natuurlijk steevast de omstandigheden van het geval terug. Zo is het dus ook in dit arrest. Volgens de Hoge Raad spelen bij de toepassing van die maatstaf alle omstandigheden van het geval een rol, waaronder de omvang van de gevorderde exhibitie en de mogelijkheid om het bestaan van de gestelde vordering met andere bewijsmiddelen te onderbouwen. ${ }^{58}$ Dit zou de opmaat kunnen zijn voor een lijstje van gezichtspunten die makkelijker in onderlinge samenhang bezien kunnen

55. HR 10 juli 2020, ECLI:NL:HR:2020:1251 (Semtex/X c.s.).

56. HR 10 juli 2020, ECLI:NL:HR:2020:1251 (Semtex/X c.s.), r.o. 3.1.4.

57. De vergelijking is eerder door een ander aan het papier toevertrouwd. Die ander wilde ik hier het krediet voor de vergelijking geven. Ik kon echter niet makkelijk meer vinden wie dat was.

58. HR 10 juli 2020, ECLI:NL:HR:2020:1251 (Semtex/X c.s.), r.o. 3.1.4. worden én waaraan bij beoordeling van een vordering tot inzage aandacht besteed moet worden, zonder dat getoetst behoeft te worden of aan elk daarvan is voldaan. De afvinklijstjes in uitspraken waarbij dat tot dusverre wel aan elk vereiste afzonderlijk wordt getoetst, zouden in dat geval tot het verleden kunnen behoren.

\section{De stip aan de horizon: voldoende aannemelijkheid én uniforme rechtsontwikkeling}

\subsection{Het arrest laat zich niet uitdrukkelijk uit over de (on)wenselijkheid van de maatstaf in het wetsontwerp}

De Hoge Raad besteedt in het Semtex-arrest niet merkbaar aandacht aan het advies van de expertgroep of het ingediende wetsontwerp. Kennen deed de Hoge Raad het advies zeker en over een concept voor het wetsontwerp had de Hoge Raad in de fase vóór indiening bij de Raad van State geadviseerd. ${ }^{59}$ Uit de conclusie van de advocaat-generaal blijkt dat het wetsontwerp in oktober 2019 daadwerkelijk aan de Raad van State was gezonden en alleen al een enkele zoekopdracht van slechts één van de betrokken raadsheren in de drie weken vóór het wijzen van het arrest zou het wetsontwerp in het blikveld van de Hoge Raad hebben gebracht.

Ook hier geldt dat het gissen is waarom van advies en wetsontwerp in het arrest geen melding is gemaakt. Vindt de Hoge Raad dat die stukken er niet toe doen, omdat hij het geschil beoordeelt naar geldend recht? Zou de Hoge Raad vinden dat zwijgen hier niet fout, maar goud is, omdat het de wetgever vrijstaat om de lat anders te leggen dan de Hoge Raad heeft gedaan? Zou de opvatting die de Hoge Raad heeft over zijn taak in de trias politica met zich brengen dat een arrest de verkeerde plek is om ongevraagd advies te geven over nog maar net aanhangige wetgeving? Zou de Hoge Raad niet nodeloos op de tenen willen gaan staan van de Minister voor Rechtsbescherming óf de expertgroep, met daarin twee niet de minsten onder de oud-raadsheren in de Hoge Raad? Iets anders? Ik weet het niet en ga er ook niet naar gissen. Liever dan dat geef ik aan hoe ik denk dat het verder moet gaan. Dat is wat mij betreft veel interessanter.

\subsection{Het vergen van voldoende aannemelijkheid is ook voor de toekomst wenselijk}

Tot enkele maanden vóór het Semtex-arrest uit 2020 was de daarin benoemde maatstaf nog geen gemeengoed. ${ }^{60}$ Inmiddels is de maatstaf uit het arrest van de Hoge Raad natuurlijk snel

59. Kamerstukken II 2019/20, 35498, nr. 3, bijlage: advies Hoge Raad.

60. Zie bijv. Hof Amsterdam 10 maart 2020, ECLI:NL:GHAMS:2020:754 (Holland Lift International c.s./Jan Accountants en Belastingadviseurs) en zie in de door de Hoge Raad voorgestane zin bijv. Hof Arnhem-Leeuwarden 11 maart 2014, ECLI:NL:GHARL:2014:2005; Hof ArnhemLeeuwarden 26 augustus 2014, ECLI:NL:GHARL:2014:6633; Hof Arnhem-Leeuwarden 16 december 2014, ECLI:NL:GHARL: 2014:9849, NJF 2015/116. 
opgepakt door feitenrechters ${ }^{61}$ en zal die in de nabije toekomst door hen worden toegepast. Ondertussen staat het de wetgever vrij om voor de verdere toekomst een eigen en dus ook andere afweging te maken, nu er geen hogere regelgeving is die tot een bepaalde te maken keuze verplicht. De tijd van een Europees uniform burgerlijk bewijsrecht is nu nog even niet daar.

Ik denk dat het verstandig is om de lat ook in de toekomst hoger te leggen dan de expertgroep voorshands wilde doen toen zij op het arrest uit 2016 respondeerde én - inderdaad terughoudendheid te betrachten bij inzageverzoeken die ingrijpend kunnen zijn en een arbeidsintensieve beoordeling kunnen vergen. Die terughoudendheid wordt alleen maar belangrijker met de gestaag toenemende opslag van gegevens op computers en in de cloud, waarmee het inzagerecht een alsmaar groter bereik krijgt.

Met wat zelfbeheersing houden wij ook de aansluiting bij hetgeen in andere landen geldt. De door de Hoge Raad gehanteerde maatstaf dat de aanspraak voldoende aannemelijk moet zijn, is ontleend aan de door de EU in 2004 vastgestelde IEHandhavingsrichtlijn en keert ook terug in de door de EU in 2014 vastgestelde richtlijn over schadevorderingen wegens inbreuken op het mededingingsrecht. ${ }^{62}$ In de toelichting op die laatste richtlijn schrijft de Europese Commissie dat zij er nauwlettend op heeft toegezien dat het voorstel met de uiteenlopende rechtsordes van de lidstaten verenigbaar is én dat het voorstel aansluit op de traditie van de overgrote meerderheid van de lidstaten. ${ }^{63}$

Als wij ook in de toekomst voldoende aannemelijkheid blijven verlangen en de lat toch wat hoger leggen dan de expertgroep voorshands voorstond, hebben wij ook minder bezweringsformules nodig dat de gevolgen voor partijen van de vereenvoudiging en modernisering van het bewijsrecht wel meevallen. In het wetsontwerp uit 2011 gaf de minister aan dat voor excessief gebruik van het inzagerecht niet gevreesd behoefde te worden. ${ }^{64}$ In het wetsvoorstel uit 2020 hanteert de minister wat de Belgen ooit arithméthique hollandaise noemden: de redenering van koning Willem I waarmee hij zichzelf aan een meerderheid hielp voor de Grondwet van zijn pas verworven koninkrijk. Dat deed hij door niet-uitgebrachte stemmen óf volgens de koning ondoordachte tegenstemmen om te katten naar stemmen vóór de Grondwet. In de toelichting op het wetsontwerp valt immers te lezen dat de werklast bij civiele

61. Zie bijv. Rb. Oost-Brabant (vzr.) 3 augustus 2020, ECLI:NL:RBOBR: 2020:3808 en Hof Den Haag 25 augustus 2020, ECLI:NL:GHDHA: 2020:1581.

62. Art. 5 lid 1 Richtlijn 2014/104/EU van het Europees Parlement en de Raad van 26 november 2014 betreffende bepaalde regels voor schadevorderingen volgens nationaal recht wegens inbreuken op de bepalingen van het mededingingsrecht van de lidstaten en van de Europese Unie.

63. Voorstel voor richtlijn van het Europees Parlement en de Raad betreffende bepaalde regels voor schadevorderingen volgens nationaal recht wegens inbreuken op de bepalingen van het mededingingsrecht van de lidstaten en van de Europese Unie, $\operatorname{COM}(2013) 404$, p. 16.

64. Kamerstukken II 2011/12, 33079, nr. 3, p. 8 procedures bij procespartijen volgens de door de overheid gehanteerde normen voor administratieve lasten niet van belang is. Want ... de kosten die met informatieverplichtingen gemoeid zijn, worden vanwege het bijzondere karakter niet als regeldruk aangemerkt. ${ }^{65}$ Een glimlach trok over mijn gezicht toen ik die redenering tot mij door liet dringen en de parallel met onze koopman-koning Willem I dacht te ontwaren. Tegelijkertijd realiseerde ik mij dat de opmerking van de minister past in een lange traditie: opvattingen over wat juridisch behoort, zijn meer dan eens meer normatief dan empirisch onderbouwd.

Wat mij betreft is de maatstaf die de Hoge Raad in het Semtex-arrest van 10 juli 2020 voorstaat de maatstaf die de minister en de wetgever ook voor de toekomst tot de hunne moeten maken. Ook dan kunnen zij trots zijn én blijven op een gemoderniseerd bewijsrecht en een rechtspleging die ook door de concentratie van het debat én actieve rechters adequate waarborgen biedt voor een beslissing op basis van een deugdelijke feitelijke grondslag. En: op hun conto schrijven dat nodeloze belasting van procespartijen en derden wordt voorkomen.

\subsection{Kortom}

Door aansluiting te houden bij de normen uit het Semtexarrest en voor inzage - kort gezegd - te verlangen dat de vordering voldoende aannemelijk is, kunnen partijen, derden én de rechter wat mij betreft vooruit met een evenwichtiger invulling van het inzagerecht. Wat mij betreft is die invulling meer gebalanceerd dan de normstelling in het door de minister ingediende wetsvoorstel tot vereenvoudiging en modernisering van het bewijsrecht. Dat wetsvoorstel zoekt voor de aanspraak op inzage aansluiting bij de normen voor het voorlopig getuigenverhoor. Daar speelt die aannemelijkheid niet of nauwelijks een rol.

De waarborgen voor een verantwoorde ontwikkeling van het inzagerecht kunnen nog verder worden versterkt, indien de minister zijn voorstel inslikt om een appelverbod in te voeren. Met dat appelverbod wil hij een einde maken aan de bestaande mogelijkheid om hoger beroep in te stellen tegen de uitspraak op een verzoek tot inzage dat voorafgaand aan een bodemprocedure is gedaan. Ik denk dat het wenselijk is om de bestaande mogelijkheid om een rechtsmiddel aan te wenden te handhaven. De rol die ook de hoven en de Hoge Raad in dat geval kunnen vervullen bij de rechtsbescherming én bij de volwassenwording van het inzagerecht zou de Minister voor Rechtsbescherming kleur op de wangen moeten geven.

65. Kamerstukken II 2019/20, 35498, nr. 3, p. 26. 